\title{
Human Impacts on the Fire Regime of Interior Alaska: Interactions among Fuels, Ignition Sources, and Fire Suppression
}

\author{
La'ona DeWilde, and F. Stuart Chapin III* \\ Institute of Arctic Biology, University of Alaska Fairbanks, Fairbanks, Alaska 99775, USA
}

\begin{abstract}
Wildfire is the major natural agent of disturbance in interior Alaska. We examined the magnitude of human impact on fire by comparing fire regime between individual $1-\mathrm{km}^{2}$ grid cells designated for fire suppression with lands where fires are allowed to burn naturally. Two-thirds of interior Alaska has an essentially natural fire regime, with few human ignitions, negligible suppression activity, and many large lightning-caused fires. In the $17 \%$ of land that is designated for fire suppression due to its proximity to communities and roads, there was a $50 \%$ reduction in the proportion of area burned from 1992-2001, relative to areas without suppression. The remaining $16 \%$ of land serves as a buffer, receives some suppression, and has an intermediate fire regime. Even though there were 50 times more fires and the fire season began two months earlier in lands designated for suppression, most of these fires were lit by people and remained small because fires tended to occur at times and places less favorable for fire spread and were more accessible
\end{abstract}

\section{INTRODUCTION}

People have always influenced the fire regime of their environment, but the nature of this interaction has changed. In the tropics, increased human settlement has increased biomass burning (Cochrane and others 1999; Levine 1991). In many

Received 5 July 2005; accepted 30 May 2006; published online 19 January 2007.

*Corresponding author; e-mail: terry.chapin@uaf.edu to fire fighters compared to lands not designated for suppression. Even in the absence of fire suppression, human-caused fires were less likely to exceed 400 ha compared to lightning-caused fires. Fire suppression reduced area burned in all fuel types but was somewhat more effective in less flammable (non-forest) vegetation. Alaska's fire policy of focusing suppression efforts on a small proportion of the fire-prone region maximizes the ecological and social benefits associated with fire-dependent ecosystem services, while minimizing the social and ecological costs of suppression. Application of this policy to other areas would require well-informed managers and stakeholders to make difficult decisions about the relative costs and benefits of fire across ecologically and culturally variable landscapes.

Key words: Alaska; climate change; fire size; fire suppression; fuel, human-caused fires; ignition; lightning-caused fires; wildfire. temperate and boreal regions, human-fire interactions have changed from a pattern of promoting fire through human ignitions (for example, indigenous burning) to one of fire suppression that reduces the areal extent of fire (Pyne 1982). After extensive wildfires in 1910, for example, the United States (U.S.) government instituted a policy of wildfire suppression, a policy that has remained largely intact to the present (Pyne 1982; Busenberg 2004). Wildfire suppression became more effective 
after World War II, when surplus aircraft were transferred to the Forest Service and assumed a key role in suppression actions (Busenberg 2004). In some regions of the western U.S., fire frequency declined during the $20^{\text {th }}$ century-particularly in open ponderosa pine savannas (Veblen and others 2000; Schoennagel and others 2004). The role of fire suppression in altering fire regime is debated, however, because $20^{\text {th }}$-century changes in fire regime coincided with increased precipitation (Graumlich 1993), a reduction in human ignitions in some rural areas (for example, cessation of railroad construction), and increased cattle grazing that reduced fine fuels (Veblen and others 2000). In other areas, such as California chaparral and high-elevation forests, fire suppression has had no detectable effect on fire regime (Keeley and others 1999; Johnson and others 1990; Schoennagel and others 2004; Keeley and Fotheringham 2003). Extensive fires in Yellowstone in 1988 and throughout the western U.S. in 2000-2003 sharpened the debate about the effects of fire suppression on fuel accumulation and future fire risk (Romme and Despain 1989; Schoennagel and others 2004). The consequences of fire suppression continue to be debated in the conterminous U.S. in part because there are no large control areas, where fires have not been suppressed. Consequently, conclusions are based on temporal variation over a time period when many factors may have simultaneously contributed to changes in fire regime.

Interior Alaska provides an opportunity to evaluate the effects of fire suppression on fire regime because fire is the principal disturbance agent in interior Alaska (Viereck 1973; Johnson 1992; Kasischke and others 2002; Yarie 1981), and Alaska has been zoned into areas designated to receive different levels of fire suppression. Fire managers in Alaska have never had sufficient resources to suppress all wildfires (Pyne 2001), so in the 1980s lands were designated to receive different levels of suppression. Lands close to roads or communities or with other high-value resources receive intensive suppression effort, whereas lands distant from human habitation receive little suppression action. This provides a spatial contrast between lands where people substantially influence fire regime through human ignitions, land-cover change, and suppression versus areas with a largely natural fire regime (Gabriel and Tande 1983; Murphy and others 2000). This zoning of fire regime formalized geographic patterns of fire suppression that tended to occur previously. An analysis of the effects of fire suppression in Alaska should therefore inform debates about the extent to which fire suppression can alter fire regime and whether suppression effect depends on vegetation type. This analysis must be done carefully, however, to control as much as possible for differences in fire detection efficiency between remote and populated areas (Bridge and others 2005; Miyanishi and Johnson 2001). In this paper we integrate databases of vegetation, fire regime, and fire suppression categories to assess the net effect of human actions on fire regime and the extent to which this reflects differences in ignition, suppression, and vegetation.

\section{MethodS}

\section{Overview of Study Design}

We studied an extensive area of Interior Alaskan boreal forest between the Brooks and Alaska Ranges to the north and south, respectively, and a maritime area to the west (Figure 1). This area is characterized by a continental climate (Fleming and others 2000; Hess and others 2001; Mock and others 1998), frequent air-mass (convective) thunderstorms and lightning strikes (Dissing and Verbyla 2003; Reap 1991), and a fire return time of 30-200 years, depending on topographically controlled vegetation mosaics (Viereck and others 1986; Yarie 1981; Kasischke and others 2002). Within this Interior Region we treated each of $448,5201-\mathrm{km}^{2}$ grid cells as data points in our analysis of the relationship among vegetation, fire policy, ignition source, and fire regime. We selected the longest time interval appropriate for each parameter that we studied.

We first examined the interactive effects of ignition source (lightning or people) and fuel type on fire size distribution by comparing grid cells that differed in fuel type. For each grid cell in a given fuel type we summed the number of lightning- and of human-caused fires in each of six fire-size categories from 1992 (the year after imagery was obtained for the first satellite-based vegetation map) to 2000 . We then compared fire size distribution on all grid cells in the study region with respect to ignition source and fuel type.

We used a similar approach to examine interactive effects of ignition source and fire policy on fire size distribution. This enabled us to assess the mechanisms (ignition and suppression) by which human actions affect fire regime. For each grid cell in a given suppression category we summed the number of lightning- and of human-caused fires in each of six fire-size categories over the time interval since suppression options were designated (1986-2000). We then compared suppression 


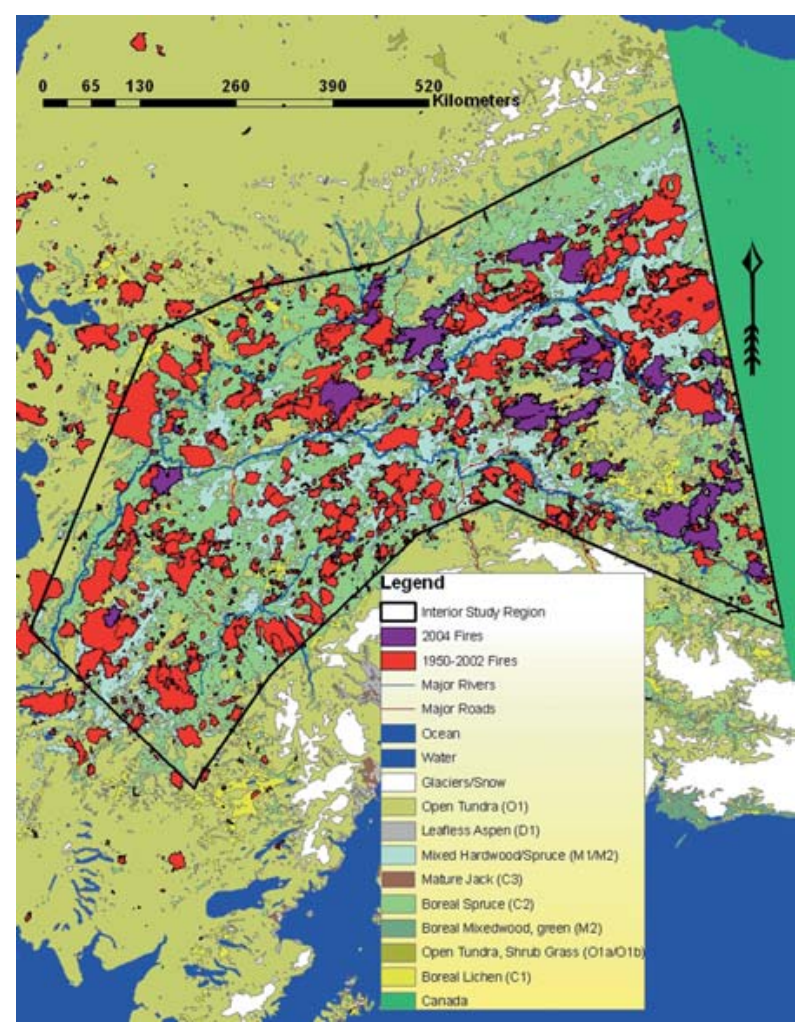

Figure 1. Map of fuel types, 1956-2003 fires larger than 400 ha, and 2004 fires larger than 400 ha. The boundary of the Interior Region of Alaska that was analyzed in this study is also shown.

categories with respect to the frequency distribution of fire sizes and the total area burned. We repeated this comparison in a single fuel type (Boreal Spruce) and ignition source (lightning) to isolate the effects of fire suppression from other potentially confounding factors.

We then examined the effect of ignition source on the seasonal pattern of start dates of fires for each grid cell over the entire fire record (19562000). This longer time interval was necessary to obtain an adequate sample size for all categories of fire starts.

\section{Fuel Types}

The vegetation of interior Alaska is a mosaic of forests, wetlands, and high-elevation tundra (Viereck and others 1986) that was mapped at $1 \mathrm{~km}$ resolution based on 1991 satellite imagery. The 24 vegetation units from this map were combined into four fuel classes that differ in flammability to produce a map of fuel types (Figure 1; R. Burgan pers. comm.; http://agdc.usgs.gov/data/projects/fhm/ $\# M ;$ 2006). The fuel classification uses the Canadian Fire Danger Rating System (Group, 1992; NIFC, 1992). The four interior Alaskan fuel types, in order of decreasing flammability (Group, 1992), are: Boreal Spruce $(\mathrm{C} 2 ; 46 \%$ of area) $>$ Mixed Hardwood/Spruce (M1/M2;28\% of area) >> Open Tundra, Shrub/Grass $(\mathrm{Ola} / \mathrm{Olb} ; 21 \%$ of area $)=$ Boreal Lichen ( $\mathrm{Cl} ; 5 \%$ of area). Thus the two most flammable fuel types occupy $74 \%$ of interior Alaska, making much of the region quite flammable under conditions of severe fire weather.

The Boreal Spruce fuel type consists mainly of continuous stands of black spruce (Picea mariana). Black spruce is highly flammable because of its fine twigs and needles, high resin content, low moisture content, and ladder-like structure that carries fire into the canopy (Viereck 1973; Johnson 1992; Kasischke and others 2000; Group 1992). Fire spread is also promoted by a flammable understory of mosses and evergreen shrubs and by a fibrous organic mat, all of which dry quickly during hot, dry weather (Johnson 1992). The large continuous stands that are typical of black spruce support fire spread, resulting in a fire return time of about 30150 years in interior Alaska (Yarie 1981 Kasischke and others 2002).

The Mixed Hardwood/Spruce fuel type includes white spruce (Picea glauca), poplar (Populus balsamifera), birch (Betula neoalaskana), and aspen (Populus tremuloides) (classified as Ml [before greenup] or M2[after green-up]). These stands are typically smaller and less continuous than Boreal Spruce. They burn less frequently in mid-summer because of higher leaf moisture and less understory moss, evergreen shrubs, and soil organic accumulation (Viereck and others 1983). This fuel type is particularly prone to spring fires before leaf-out, when dry grass and litter burns readily. White spruce forests have a 100-200 year fire return time in interior Alaska (Yarie 1981). Poplar, birch, and aspen are typically mid-successional forest types within the white spruce successional sequence (Van Cleve and others 1991).

The Open Tundra, Shrub/Grass fuel type consists of open tundra (Ola), which has generally low flammability because of high moisture content and small fuel loads, and grass meadows (Olb), which are quite flammable in spring because of dry leaf litter, but less flammable during the growing season because of their high leaf moisture content.

The Boreal Lichen (C1) fuel type consists of open savanna-like black spruce with a sparse ground cover and shallow organic mat that is less flammable than the Boreal Spruce or Mixed Hardwood Spruce. The fire return times of Open Tundra, Shrub/Grass and Boreal Lichen have not been documented in interior Alaska but may exceed 200 y (Wein 1976). 

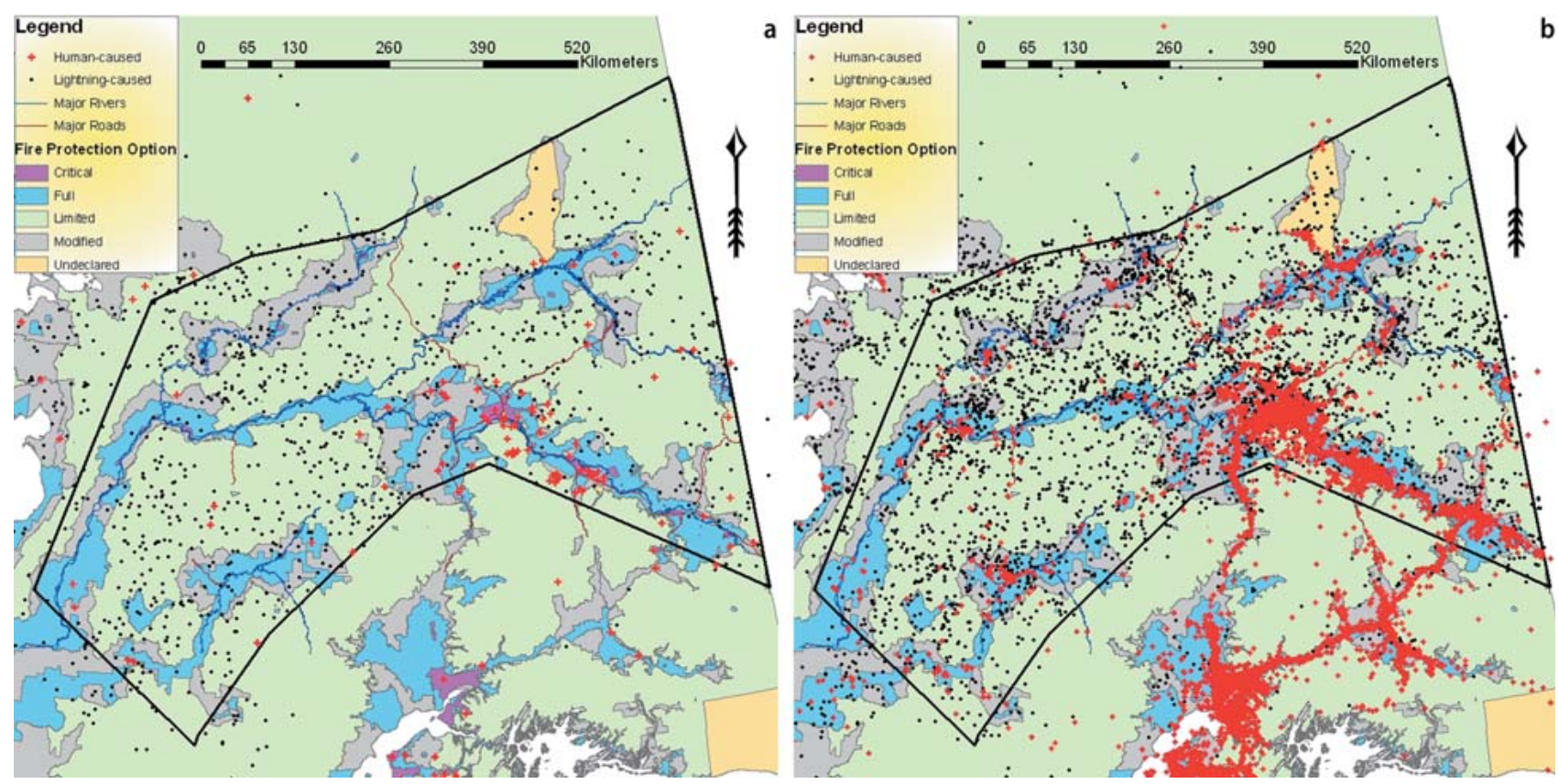

Figure 2. Maps of lightning- and human-caused fires larger than 400 ha (left) and smaller than 4 ha (right). The locations of fire management options are also shown.

\section{Suppression Categories}

In the 1980's, interior Alaska was classified into four management options (Critical, Full, Modified and Limited) that differ in priority for suppression (Roessler 1997; Kasischke and others 2002; Todd and Jewkes 2006). Lands designated as Critical or Full receive highest priority for suppression and are generally located around roads or human settlements. These lands are usually surrounded by a buffer of land classified as Modified, where fires may or may not be attacked depending on resource availability, threats to human life and property, and prevailing weather. Most fires on Limited lands are only monitored, although small areas around remote cabins are sometimes protected. About $1 \%$ of Alaska's land is under the Critical management option, 16\% under Full, 16\% under Modified, and $67 \%$ under Limited management option. The $1-\mathrm{km}$ resolution database on management options for Alaska was obtained from the Alaska Fire Service (AFS) (http://agdc.usgs.gov/ data/projects/fhm/\#M; 2006) (Figure 2).

\section{Ignitions and Fire Number}

Data on number of fires and their cause of ignition were provided by AFS (http://agdc.usgs.gov/2006). We combined information for fires since 1956 from a tabulated database of all fires (including fires smaller than $0.4 \mathrm{ha}$ ) and a large-fire GIS database
(Kasischke and others 2002) that contains only fires larger than 400 ha prior to January 1987, and fires larger than 40 ha after that date (Figure 2). Location and timing of cloud-to-ground lightning strikes are monitored by triangulation from lightning detectors in interior Alaska and western Canada (Dissing and Verbyla 2003). Fires are classified by AFS as human-caused if no lightning strikes were recorded at the fire location for approximately 5 days prior to first detection of the fire or if there was good evidence of human influence. Prior to 1981 there were no lightning detectors, so fires were assumed to be lightning-caused if no evidence of human influence was found.

There are several limitations to the Alaskan fire record. Fires that are distant from the road or river system are likely assumed to be lightning-caused, especially prior to 1981, whereas fires on the road or river system are more likely to be examined for evidence of human influences. The database includes only fires that were detected, and detection efficiency is probably lower in remote areas than in areas designated for suppression (Miyanishi and Johnson 2001; Bridge and others 2005). Fires in remote areas are usually recorded only if seen by private, commercial, or fire-observing aircraft. Spotting aircraft are usually deployed after intense lightning activity, when most fires occur. The record also excludes some fires that were no longer burning when first detected (K. Slaughter, Personal 
Communication). Both sources of error lead to an under-representation of small fires, particularly in remote areas. These small fires influence data on fire number but have little influence on area burned (Kasischke and others 2002; Stocks and others 2002).

\section{Fire Size, Area Burned, and Start Date}

We used the AFS database described above for information on initial and final fire location and size and start date. We determined the fuel type where each fire began based on the initial location of each fire and the GIS database on fuel types. For graphical presentation, we grouped fires into six size classes that were selected to show the entire spectrum of fire sizes and the major differences among fuel types, ignition sources, and management options. Data on fire density are expressed per unit area of fuel type, management option, or month of ignition to account for differences in area among categories. In the database fire size is defined as the outer perimeter of the fire. It overestimates the actual area burned, because it is not corrected for islands and fingers of unburned vegetation within the fire perimeter. In large fires in the Canadian boreal forest, unburned islands are a small proportion of the area within a fire scar $(<3-$ $5 \%$ ) (Kafka and others 2001; Eberhardt and Woodard 1987), but the magnitude of this error in Alaskan wildfires is unknown. The start date recorded for a fire is the date of its discovery even if the fire began burning several days previously. The time interval between the actual start date and the discovery date could be greater in remote areas than in more traveled areas. However because we aggregate data to monthly time periods, the error should be relatively small. After 1980, the quality of the data record is considered excellent (Murphy and others 2000; Kasischke and others 2002), but before this date there was a lower detection efficiency, periods of missing data, and less accurate mapping of fire perimeters. Most sources of error have less impact on comparisons among regions (the objective of our study) than in comparisons among time periods (which we do not address).

\section{RESUlts}

\section{Effects of Fuel Type and Ignition Source}

Lightning, the natural ignition source in interior Alaska, produced fires that ranged in size by several orders of magnitude (Figure 3). The most frequently recorded lightning-caused fires were $0.4-4$ ha in size. Fires that became larger than 40 ha be-
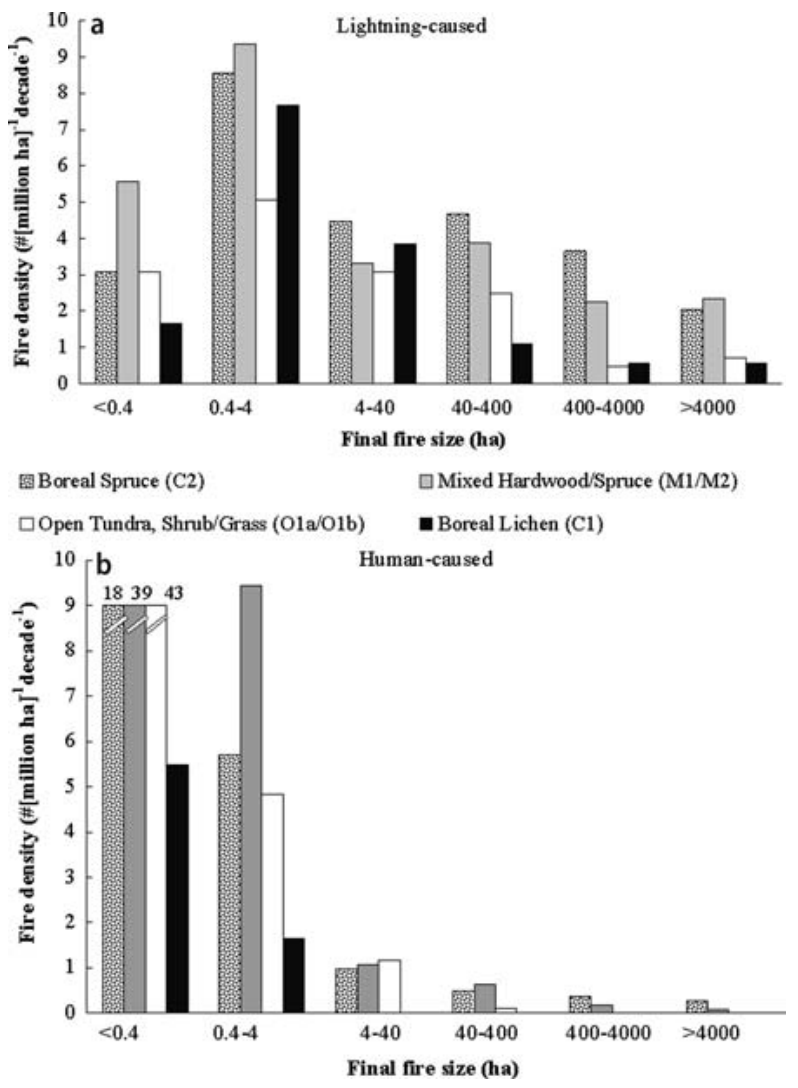

Figure 3. Frequency distribution of final fire sizes of lightning- (top) and human-caused (bottom) fires in the four major fuel types in the Interior Region of Alaska (1992-2000). Data are expressed as fire density (\# [million ha of fuel type] ${ }^{-1}$ decade $^{-1}$ ).

gan most frequently in forested fuel types (Boreal Spruce and Mixed Hardwood/Spruce). Although few fires exceeded 400 ha in non-forested ecosystems (Open Tundra or Boreal Lichen), fires smaller than 40 ha occurred frequently in these fuel types. These results suggest that large lightning-caused fires were most likely to start in forested fuel types.

Recorded human-caused fires differed from the lightning fires described above in both their typical size and in the fuel types in which they occurred. Most $(78 \%)$ human-caused fires were less than 0.4 ha in size (Figure 3), and these occurred most frequently in moderately flammable fuel types (Mixed Hardwood/Spruce and Open Tundra, Shrub/Grass) (Table 1). The human-caused fires larger than 40 ha were primarily in forested fuel types (Boreal Spruce or Mixed Hardwood/Spruce fuel types), just as with lightning-caused fires. Within the Interior Region as a whole, 89\% of the recorded fires smaller than 0.4 ha were human-caused. Human ignitions were, however, of negligible importance for fires larger than 40 ha 
Table 1. Areal Extent, Area Burned (1992-2001), and Density of Fires per Decade (1992-2000) in the Major Fuel Types in the Interior Region

\begin{tabular}{|c|c|c|c|c|}
\hline \multirow[b]{2}{*}{ Characteristic } & \multicolumn{4}{|c|}{ Fuel type } \\
\hline & $\begin{array}{l}\text { Boreal } \\
\text { Spruce }\end{array}$ & $\begin{array}{l}\text { Mixed Hardwood } \\
\text { Spruce }\end{array}$ & $\begin{array}{l}\text { Open Tundra, } \\
\text { Shrub/Grass }\end{array}$ & $\begin{array}{l}\text { Boreal } \\
\text { Lichen }\end{array}$ \\
\hline Areal extent (\% of area) & 46 & 28 & 21 & 5 \\
\hline \multicolumn{5}{|l|}{ Area burned } \\
\hline$\left(\%\right.$ of fuel type decade $\left.{ }^{-1}\right)$ & 5.9 & 5.2 & 2.0 & 2.3 \\
\hline (\% of total burned area) & 58 & 29 & 11 & 2 \\
\hline \multicolumn{5}{|c|}{ Density of fires (\# [million ha $]^{-1}$ decade $^{-1}$ ) } \\
\hline Total fires & 47.0 & 69.7 & 58.4 & 20.3 \\
\hline Lightning-caused fires & 23.6 & 24.0 & 13.6 & 13.9 \\
\hline Human-caused fires & 23.4 & 45.7 & 44.8 & 6.4 \\
\hline (\% lightning-caused) & 50 & 34 & 23 & 68 \\
\hline (\% human-caused) & 50 & 66 & 77 & 32 \\
\hline
\end{tabular}

in size (Figure 3) and therefore accounted for only $4.6 \%$ of the total area burned in the Interior Region from 1992-2001.

\section{Effects of Fire Management and Ignition Source}

The density of lightning-caused fires larger than 400 ha was greater on lands designated for low levels of suppression (Limited and Modified lands) than on Critical and Full lands (Figure 4). In contrast, lightning-caused fires smaller than 0.4 ha occurred primarily on Full and Critical lands, where suppression was most active. This pattern was even more pronounced with human-caused fires, where human-caused fires larger than 400 ha rarely occurred on Full or Critical lands but occurred occasionally on Limited lands. Fires smaller than 0.4 ha were 100 times more likely to occur on Full and Critical lands than on Limited lands. These results clearly demonstrate that fire suppression or some other characteristics of Full and Critical lands (for example, magnitude of human disturbance) greatly reduced the probability of large fires. Visual inspection of the fire maps (Figure 2) also shows that most large fires occurred on Limited lands, whereas small fires were concentrated in areas receiving maximum suppression effort (Full and Critical lands). The large fires that occurred on Full and Critical lands occurred primarily during conditions of severe fire weather, when suppression activities are least effective (data not shown).

To separate explicitly the effect of suppression from potential effects of ignition source and fuel type, we examined lightning-caused fires in the Boreal Spruce fuel type. A higher density of fires

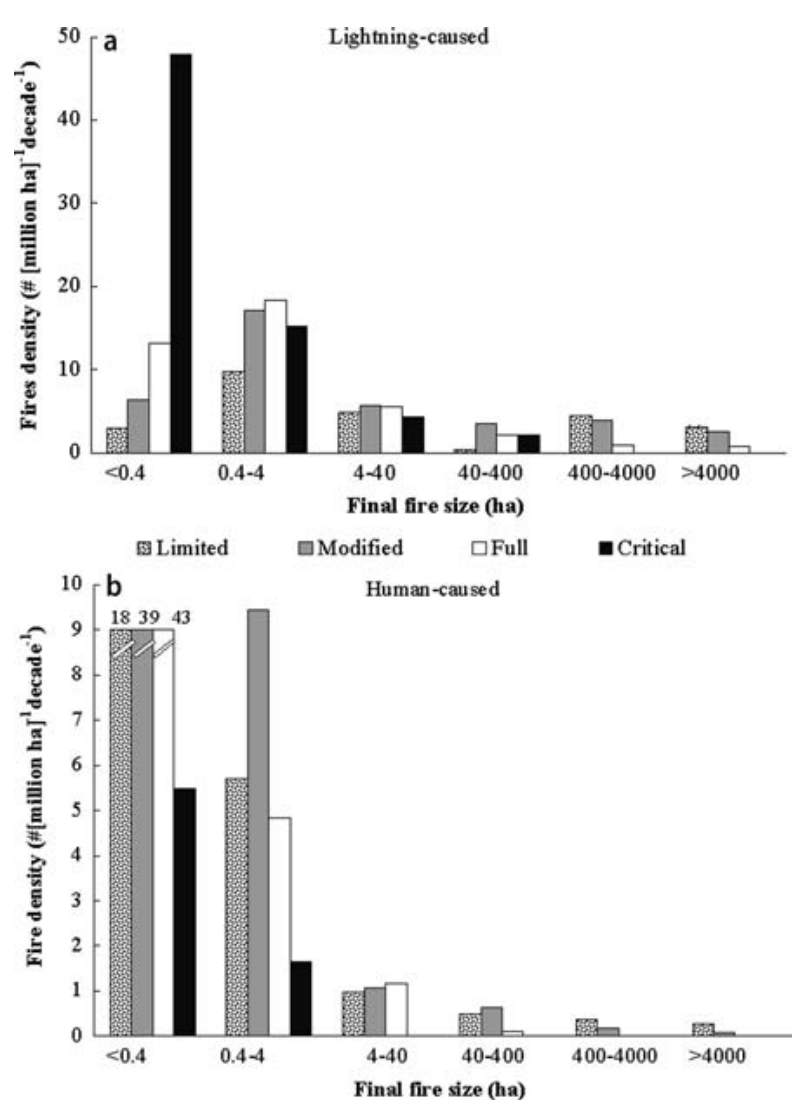

Figure 4. Frequency distribution of final fire sizes of lightning- (top) and human-caused (bottom) fires in the four fire management options in the Interior Region of Alaska (1986-2000). Data are expressed as fire density (\# [million ha of management option] ${ }^{-1}$ decade $^{-1}$ ).

larger than 40 ha occurred in Limited lands, but smaller fires were recorded most frequently in the Full and Critical lands (Figure 5). Because 

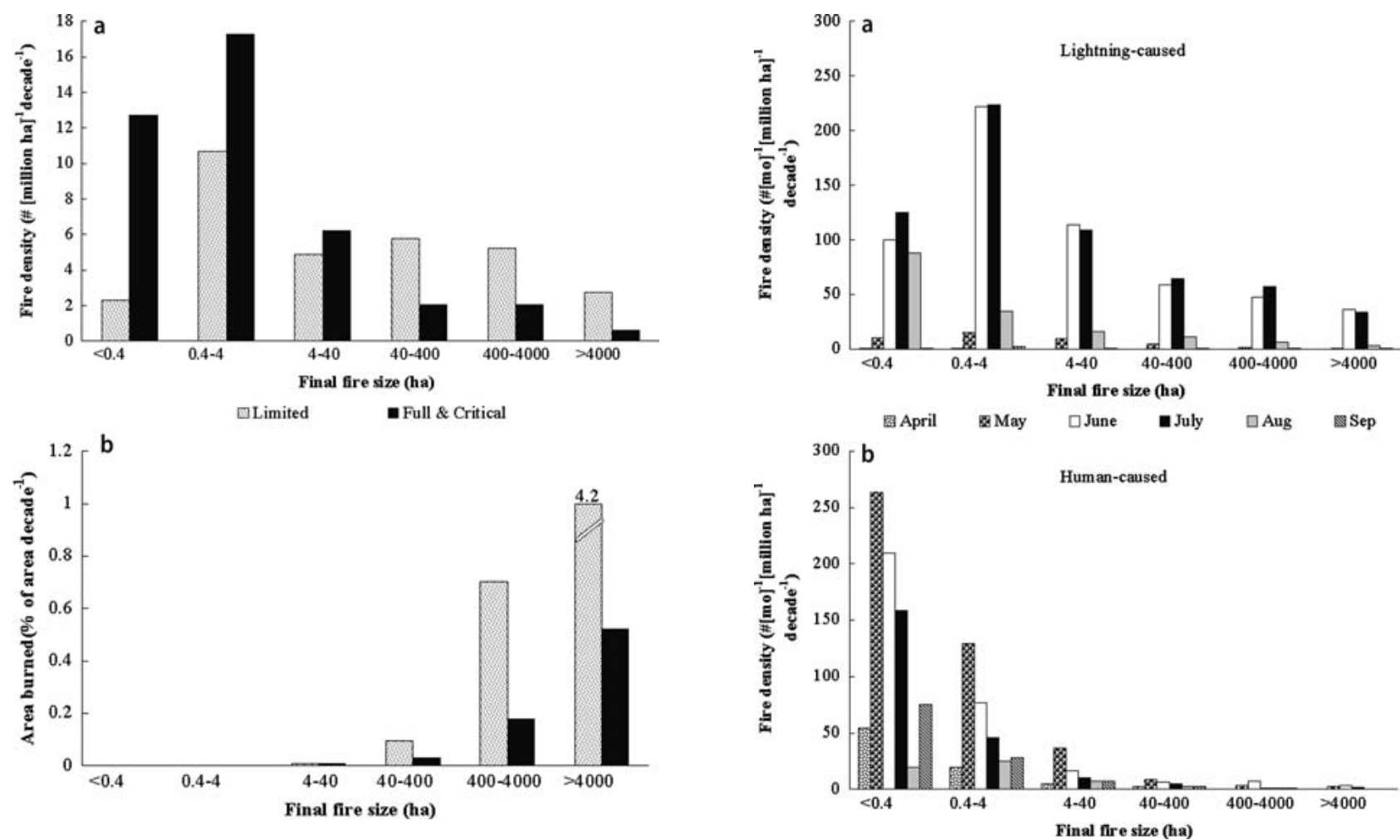

Figure 5. Frequency distribution of final fire sizes (top) and area burned (bottom) of lightning-caused fires that occurred in the Boreal Spruce fuel type, comparing Limited vs. Full-plus-Critical management options of the Interior Region of Alaska (1986-2000). Data are expressed as fire density (\# [million ha of management option in Boreal Spruce] ${ }^{-1}$ decade $^{-1}$ ) and area burned ([\% of Boreal Spruce area in designated management option burned] decade ${ }^{-1}$ ).

suppression kept most fires in Full and Critical lands from becoming large, a much smaller proportion of the land burned in the Full and Critical lands than in Limited lands. For the Interior Region as a whole, lightning fires larger than 400 ha accounted for $97 \%$ of the Boreal Spruce area burned, and most of these fires occurred in Limited lands (Figure 5).

\section{Effects of Seasonality and Ignition Source}

Most (85\%) lightning-caused fires began in June and July (Figure 6), after soils dried from snowmelt, and convective thunderstorms (which produce lightning with only scattered rain) were frequent (Dissing and Verbyla, 2003), but before the summer rains began in late July and August. The few recorded lightning-caused fires that began in May and August generally remained smaller than 4 ha.

Human ignitions extended the length of the fireignition season by about two months. Human ignitions occurred most frequently in May (Fig-

Figure 6. Frequency distribution of final fire sizes of lightning- (top) and human-caused (bottom) fires that were first detected in different months in the Interior Region of Alaska (1956-2000). Data are expressed as fire density (\# month ${ }^{-1}$ [million ha] ${ }^{-1}$ decade $^{-1}$ ).

ure 6). Most of these spring fires were ground fires that occurred in Open Tundra, Shrub/Grass or Mixed Hardwood/Spruce fuel type (data not shown). They burned dead grass litter before new green leaves (with higher moisture content) emerged. Most $(85 \%)$ early spring, late summer, and fall fires (months of April, May, August and September) were smaller than 4 ha. The few human-caused fires larger than 40 ha began primarily in May or June.

\section{Effects on Area Burned}

An analysis of total area burned integrates the information presented above on fire size and number. Fires that began in June and July accounted for $92 \%$ of the area burned in the Interior Region from 1956 to 2000 (Figure 7). For this 45year time period lightning-caused fires accounted for $91 \%$ of the area burned. Only for fires that started in May and June did human ignitions contribute significantly to area burned.

Management categories differed in proportion of fuels burned per unit area (Figure 8, Table 2). Most fuel types burned most extensively in Limited lands 


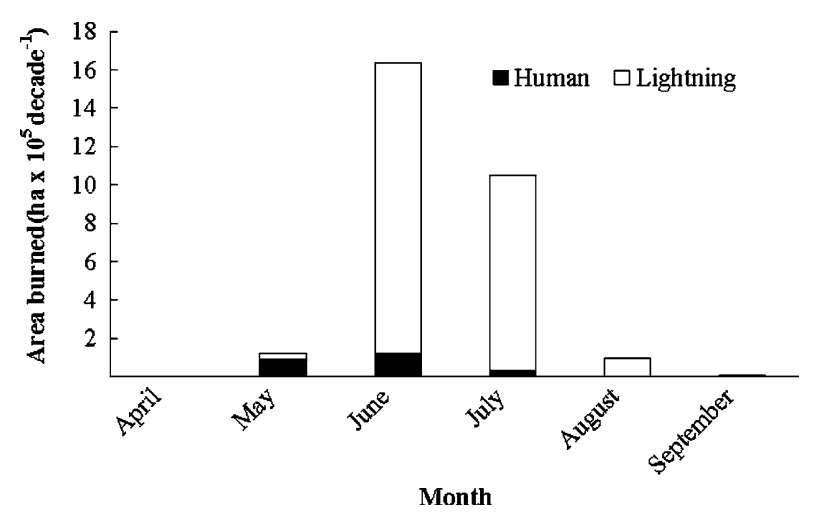

Figure 7. Total area burned in fire starts occurring in different months due to lightning- vs. human-caused fires in the Interior Region of Alaska (1956-2000). Fires were assigned to the month in which they were first detected.

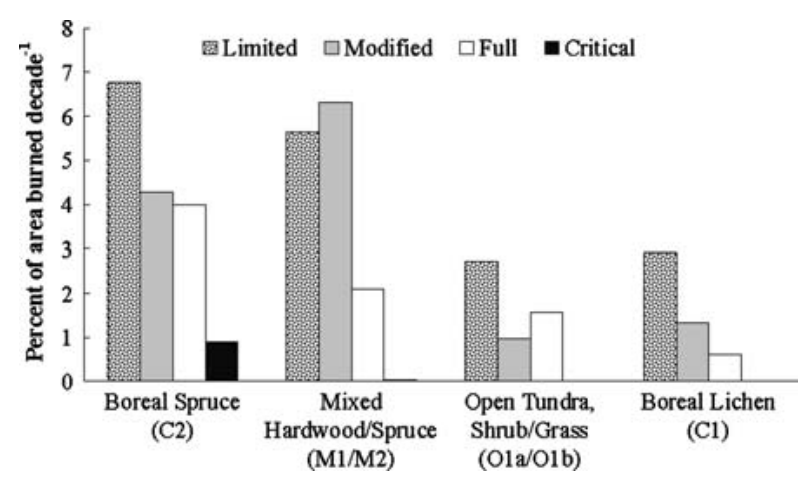

Figure 8. Proportion of each major fuel type that burned within each management option in the Interior Region of Alaska (1992-2001). Data are expressed as area burned ( $\%$ of the total area of a given fuel type present in a given management option).

and burned least extensively in Full and Critical lands. The major exception was Mixed Hardwood/ Spruce, which burned most extensively in Modified lands (closely followed by Limited lands). In all fire-management zones forested ecosystems burned more extensively than non-forested ecosystems and generally followed the following ranking: Boreal Spruce $\geq$ Mixed Hardwood/Spruce $>$ Open Tundra, Shrub/Grass $\geq$ Boreal Lichen.

Fuel types differed substantially in their contributions to total area burned, due to differences in both flammability and abundance, with Boreal Spruce accounting for $58 \%$ of the area burned, Mixed Hardwood/Spruce 29\%, Open Tundra, Shrub/Grass $11 \%$, and Boreal Lichen 2\% (Table 1). About $77 \%$ of the area burned for each of these fuel types occurred in Limited lands $(67 \%$ of the land area), and about $9 \%$ of the area burned occurred on Critical and Full lands (17\% of the land area) (Figure 9). A slightly larger proportion of forested fuel types (10.4\% of Boreal Spruce and $8.6 \%$ of Mixed Hardwood/Spruce) than of nonforested fuel types $(7.7 \%$ of Open Tundra, Shrub/ Grass and $3.2 \%$ of Boreal Lichen) burned in Critical-plus-Full lands. Across all fuel types, about twice as large a proportion of the total area burned in Limited (18.2\% of the area per decade) as in Full + Critical lands $(9.2 \%$ of the area per decade).

\section{Discussion}

\section{Effects of Fire Suppression Designation}

Despite 50 times greater density of fires, there was a $50 \%$ decrease in area burned in those parts of interior Alaska where people live and suppress fires compared to areas without suppression. This indicates that fire suppression had a greater effect on area burned than did human ignitions. This effect of suppression category could not be explained by spurious correlations with ignition source or landcover type because, when we controlled for regional variation in these factors by considering only lightning fires in Boreal Spruce forests, suppression reduced area burned to an even greater extent ( $73 \%$ decrease).

Fire suppression is effective in Alaska in part because fire managers concentrate their efforts in a relatively small proportion $(17 \%)$ of interior Alaska. In these areas, roads and proximity to fire control centers improve access for fire fighters. Consequently, fires are likely to be attacked when small, which greatly reduces their average final size and area burned (DeWilde 2003; Cumming 2005). In both Alaska and Canada, the density of large fires is the primary determinant of total area burned (Miyanishi and Johnson 2001; Kasischke and others 2002).

Although we restricted our analysis to the time period when fire statistics are of highest quality (Kasischke and others 2002), a lower efficiency of detecting fires in remote areas undoubtedly contributed to the small number of small fires recorded on Limited lands (Miyanishi and Johnson 2001; Bridge and others 2005). This probably explains why 1.7 times more lightning-caused fires were recorded on Critical-plus-Full lands (64 fires [million ha] ${ }^{-1}$ decade $^{-1}$ ) than on Limited lands (38 fires [million ha] ${ }^{-1}$ decade $^{-1}$ ) (Table 2). Even this presumed difference in detection efficiency cannot explain the 50 times greater density of total fires on Critical-plus-Full lands than on Limited lands. 
Table 2. Areal Extent, Area Burned (1986-2001), and Density of Fires per Decade (1986-2000) of Management Options in the Interior Region

\begin{tabular}{|c|c|c|c|c|}
\hline \multirow[b]{2}{*}{ Characteristic } & \multicolumn{4}{|c|}{ Management option } \\
\hline & Critical & Full & Modified & Limited \\
\hline Areal extent ( $\%$ of area) & 1 & 16 & 16 & 67 \\
\hline \multicolumn{5}{|l|}{ Area burned } \\
\hline$\left(\%\right.$ of zone decade $\left.{ }^{-1}\right)$ & 0.8 & 5.2 & 11.3 & 12.7 \\
\hline ( $\%$ of total burned area) & 0.07 & 7.4 & 16.2 & 76.3 \\
\hline \multicolumn{5}{|c|}{ Density of fires (\#[million ha $]^{-1}$ decade $^{-1}$ ) } \\
\hline Total fires & 2300 & 152 & 69 & 47 \\
\hline Lightning-caused fires & 105 & 61 & 59 & 38 \\
\hline Human-caused fires & 2195 & 91 & 11 & 8 \\
\hline (\% lightning-caused) & 5 & 40 & 86 & 81 \\
\hline (\% human-caused) & 95 & 60 & 14 & 19 \\
\hline
\end{tabular}

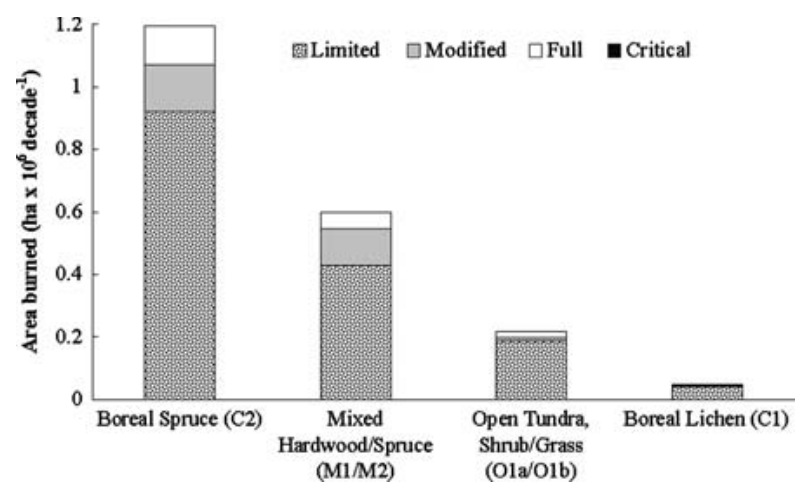

Figure 9. Total area burned per fuel type within each management option (1992-2001).

The effectiveness of fire suppression in reducing area burned in interior Alaska contrasts strikingly with the southern boreal forest, where fire suppression has not affected fire frequency or area burned (Johnson and others 1990; Romme and Despain 1989; Bridge and others 2005). This regional difference probably reflects differences in climate and/or vegetation. Natural fires in Interior Alaska are mixed-severity fires that are carried primarily by ground fuels but frequently spread rapidly by moving into the canopy. These are intermediate between crown-fire and ground-fire ecosystems (Schoennagel and others 2004). Ecosystems characterized by high-intensity crown fires (for example, high-elevation lodgepole, spruce, and fir forests in the western U.S.) show no reduction in fire frequency during the era of fire suppression (Schoennagel and others 2004; Romme and Despain 1989). This contrasts with ground-fire ecosystems (for example, open stands of ponderosa pine and giant sequoia with short pre-suppression fire return intervals) (Veblen and others 2000; Swetnam 1993; Kilgore and Taylor 1979), where fire suppression reduced fire frequency, leading to the accumulation of surface and ladder fuels and increased the risk of extensive crown fires (Covington and Moore 1994; Schoennagel and others 2004).

\section{Human Ignitions}

Even though human ignitions accounted for $62 \%$ of the fires in the Interior Region between 1992 and 2001 , they accounted for only $4.6 \%$ of the total area burned. Over a longer time period (19562000 ) they accounted for $9 \%$ of area burned (Figure 7). This supports earlier conclusions (Kasischke and others 2000) that human activities have only a modest effect on the total area burned in interior Alaska. Most $(77 \%)$ of the area burned occurred on Limited lands (Figure 9; Table 2), which have an essentially natural fire regime.

There are several reasons why human ignitions are less effective than lightning in burning Alaskan forests: (1) Most (99\%) human-caused fires occur on lands designated for fire suppression (Figure 4) and are therefore likely to be put out at a small size, because they are often reported right away, are accessible to fire crews, and are attacked at a small size with large amounts of fire-fighting resources (Cumming 2005). (2) About 55\% of humancaused fires are lit outside of the peak (June-July) season of lightning-caused fires (Figure 6) and are therefore less likely to encounter dry fuels and spread over large areas. (3) Finally, people often light fires in Mixed Hardwood/Spruce and Open Grass fuel types (Figure 3), which occur in populated areas because they are products of human 
disturbance and are preferred for home sites and recreation. These fuel types are less likely to burn than Boreal Spruce when lightning-caused fires predominate.

\section{Effects of Fuel Type}

On a unit area basis, most lightning-caused fires in interior Alaska started in those fuel types that Canadian fire managers had previously classified as being most flammable (Johnson 1992; Group 1992): Boreal Spruce $\geq$ Mixed Hardwood/Spruce $>$ Open Tundra, Shrub $/$ Grass $=$ Boreal Lichen (Figure 3; Table 1). These patterns reflect ecosystem differences in understory and tree flammability and in the size and continuity of stands (see site description). In addition, Boreal Spruce has a higher lightning strike density than other fuel types at a given elevation (Dissing and Verbyla 2003) because its dark, structurally complex canopy absorbs more radiation (low albedo) and transfers it to the atmosphere, fostering convection and the formation of air-mass thunderstorms (Dissing and Verbyla 2003; Baldocchi and others 2000; Chapin and others 2000; Chambers and Chapin 2002). Open Tundra and Boreal Lichen have a low fire frequency in part because they occur predominantly at high elevations where summer temperatures and lightning strike densities are low (Reap 1991; Dissing and Verbyla 2003; Kasischke and others 2002). The area of Boreal Spruce that burns is twice as great as that of the next most flammable fuel type (Mixed Hardwood/Spruce) and 24 times greater than the least flammable fuel type (Boreal Lichen) (Figure 9) because the most flammable fuel types are also most widespread in the Interior Region.

Under conditions of severe fire weather, when most large fires occur, almost any boreal vegetation supports fire spread (Kasischke and others 2002), although tundra is less fire-prone than forest (Wein 1976). We would therefore expect to see small differences among fuel types in large fires. Consistent with this expectation, the two forested fuel types (Boreal Spruce and Mixed Hardwood/Spruce) were similar in the density of fires larger than 4000 ha, with open fuel types (Open Tundra, Shrub/ Grass and Boreal Lichen) having fewer very large fires (Figure 3). Nonetheless, there were substantial differences among all fuel types in number of fires per unit area in intermediate-sized fires, indicating that vegetation differences in flammability had a strong effect on fire regime, particularly under conditions of moderate fire weather (intermediate fire sizes).

\section{Effects of Seasonality}

Although human activities caused the fire season to begin substantially earlier (Figure 6), this had only a modest effect on area burned except in Mixed Hardwood/Spruce and Open Grasslands (Figure 7). Here fire is carried primarily by dead grass and tree litter, producing a fuel that is driest in May before new leaves emerge. There is therefore an interaction between fuel type and month of ignition. Over the last 50 years, the length of the growing season has increased by $2.6 \mathrm{~d} \mathrm{decade}^{-1}$ (Keyser and others 2000). If this trend continues, the length of the fire season, which is now about 3-6 weeks in an "average" year, could double before the end of the $21^{\text {st }}$ century.

Most lightning-caused fires began in June and July regardless of their final size (Figure 6). Large fires therefore differed from small ones primarily in the length of time that they burned, rather than the month in which they started. In dry years, fires often continue burning until late August or September, occasionally continuing to burn the following spring (Kasischke and others 2002).

\section{Conclusions and Societal Implications}

Our results show that fire suppression is effective in reducing area burned in Interior Alaska on lands designated for suppression. Although areas zoned for fire suppression have more roads and fields than remote lands, these fuel breaks are relatively sparse, and, when the analysis is controlled for land-cover type, suppression effects are still strong. In the short term, the concentration of fire suppression efforts near resources valued by society minimizes social costs by reducing risks to human life and property and health risks from smoke. Fire suppression also provides fire-fighting jobs, which are important to the economy of rural communities and provide important career and social experiences that lead to other job opportunities. On the other hand, fire provides social benefits by reducing future fire risk and rejuvenating those ecosystem services that characterize early and mid-successional stands. These include mushrooms, berries, moose, and fur-bearers (Chapin and others 2003).

Over the long term, the reduction in area burned resulting from fire suppression increases the areal extent of late-successional Boreal Spruce in those areas where fire suppression has been applied, which increases the potential for large future fires (Chapin and others 2003). This could create a situation in which nature takes control, and large fires eventually burn the area, regardless of the suppression efforts applied. 
We suggest that the current Alaskan fire policy reduces the social costs of fire, while maximizing the ecological and social benefits. Designation of two-thirds of the land to receive a natural fire regime, with minimal human interference, minimizes suppression costs and allows substantial rejuvenation of ecosystem services associated with early successional stands. Suppression is concentrated on only $17 \%$ of the land where the negative impacts of fire on life, health, and property are of greatest societal concern. Alternative policy options, such as prescribed fire, mechanical fuel reduction, or other land clearing activities that break up expanses of continuous vegetation, can then be focused on these relatively small accessible areas of land, whose management is of greatest concern to people. Perceived shortcomings of the current policy involve debates about which lands should receive highest priority for suppression, not about the validity of a policy that zones some lands for suppression and others for natural fire regime (Todd and Jewkes 2006).

The effectiveness of the current fire suppression policy may decline with time if (1) a larger proportion of land succeeds to late-successional Boreal Spruce due to fire suppression (Chapin and others 2003), (2) climate continues to warm and permafrost thaws, producing drier fuels and more frequent crown fires (Serreze and others 2000; Keyser and others 2000), (3) vegetation continues to change in response to climate warming (Chapin and others 2006), (4) the human population continues to double every 30 years (Anonymous 1997), and/or (5) funding for fire suppression declines. Each of these current trends is likely to continue, and any of them might require suppression activities to focus on even smaller land areas and/or an active management of landscapes to reduce the probability of large fires. Proactive management to reduce flammability of critical landscapes now, in anticipation of these likely future changes, could greatly reduce the social and economic costs of future fires. However, the public response to the record 2004 fire season in Alaska (Figure 1) was to urge more extensive fire suppression (Todd and Jewkes 2006), which exacerbates rather than reduces the long-term likelihood of future fire risk to life and property. Decisions that change the balance between areas of fire suppression, prescribed fire, and natural fire regime will require (1) careful consideration of their ecological and social consequences and (2) the development of institutions that provide informed participation by stakeholders in the decision-making process. The desirable features of Alaska's fire policy can be applied in other areas of the boreal forest only if managers and stakeholders are prepared to make difficult decisions about the relative costs and benefits of fire now and in the future across ecologically and culturally variable landscapes.

\section{ACKNOWLEDGEMENTS}

We thank the Alaska Fire Service for use of facilities and databases; Mary Lynch, Lynette Nakazawa, Dave Verbyla, and Scott Rupp for assistance with databases and GIS analyses; and Cath Thompson, Dave Verbyla, Scott Rupp, Ed Murphy and five anonymous reviewers for critical review of the manuscript. Partial funding for the research was provided by the IGERT (Integrative Graduate Education and Research Training) program in Resilience and Adaptation (NSF grant DEB0114423), the Alaska Human-Fire Interaction project (NSF grant OPP-0328282), and the Bonanza Creek LTER (Long-Term Ecological Research) program (NSF grant DEB-0080609 and U.S. Forest Service grant PNW01-JV11261952-231).

\section{REFERENCES}

Anonymous. 1997. The Alaska Almanac: Facts about Alaska, 21 ed. Anchorage: Alaska Northwest Books.

Baldocchi D, Kelliher FM, Black TA, Jarvis PG. 2000. Climate and vegetation controls on boreal zone energy exchange. Global Change Biol 6(Suppl. 1):69-83.

Bridge SRJ, Miyanishi K, Johnson EA. 2005. A critical evaluation of fire suppression effects in the boreal forest of Ontario. Forest Sci 51:41-50.

Busenberg GJ. 2004. Wildfire management in the United States: The evolution of a policy failure. Rev Policy Res 21:145-156.

Chambers SD, Chapin FS III. 2002. Fire effects on surfaceatmosphere energy exchange in Alaskan black spruce ecosystems: Implications for feedbacks to regional climate. J Geophys Res 108:8145, doi:8110.1029/2001JD000530.

Chapin FS III, and others. 2000. Arctic and boreal ecosystems of western North America as components of the climate system. Global Change Biol 6(Suppl. 1):1-13.

Chapin FS III, Oswood MW, Van Cleve K, Viereck LA, Verbyla DL (Editors). 2006. Alaska's Changing Boreal Forest. New York: Oxford University Press.

Chapin FS III, and others. 2003. Planning for resilience: Modeling change in human-fire interactions in the Alaskan boreal forest. Frontiers Ecol Environ 1:255-261.

Cochrane MA, and others. 1999. Positive feedbacks in the fire dynamic of close canopy tropical forests. Science 284:18321835 .

Covington WW, Moore MM. 1994. Southwestern ponderosa forest structure: Changes since Euro-American settlement. J Forestry 92:39-47.

Cumming SG. 2005. Effective fire suppression in boreal forests. Can J Forest Res 35:772-786. 
DeWilde L. 2003. Human Impacts on the Fire Regime of Interior Alaska. M.S. Thesis. Department of Biology and Wildlife. Fairbanks, Alaska: University of Alaska Fairbanks.

Dissing D, Verbyla D. 2003. Spatial patterns of lightning strikes in interior Alaska and their relations to elevation and vegetation. Can J Forest Res 33:770-782.

Eberhardt KE, Woodard PM. 1987. Distribution of residual vegetation associated with large fires in Alberta. Can J Forest Res 17:1207-1212.

Fleming MD, Chapin FS III, Cramer W, Hufford G, Serreze MC. 2000. Geographic patterns and dynamics of Alaskan climate interpolated from a sparse station record. Global Change Biol 6(Suppl. 1):49-58.

Gabriel HW, Tande GF. 1983. A regional approach to fire history in Alaska. U.S.D.I. Bureau of Land Management.

Graumlich LJ. 1993. A 1000-year record of temperature and precipitation in the Sierra Nevada. Quat Res 39:249-255.

Group FCFD. 1992. Development and structure of the Canadian forest fire behavior prediction system. Ottawa: Science and Sustainable Development Directorate, Forestry Canada. p $1-62$.

Hess JC, Scott CA, Hufford GL, Fleming MD. 2001. El Niño and its impact on fire weather conditions in Alaska. Int J Wildland Fire 10:1-13.

Johnson EA. 1992. Fire and Vegetation Dynamics. Studies from the North American Boreal Forest. Cambridge: Cambridge University Press.

Johnson EA, Fryer GI, Heathcott MJ. 1990. The influence of man and climate on frequency of fire in the interior wet belt forest, British Columbia. J Ecol 78:403-412.

Kafka V, Gauthier S, Bergeron Y. 2001. Fire impacts and crowning in the boreal forest: Study of a large wildfire in western Quebec. Int J Wildland Fire 10:119-127.

Kasischke ES, O'Neill KP, French NHF, Bourgeau-Chavez LL. 2000. Controls on patterns of biomass burning in Alaskan boreal forests. In: Kasischke ES, Stocks BJ, editors. Fire, Climate Change, and Carbon Cycling in the North American Boreal Forest. New York: Springer-Verlag. p 173-196.

Kasischke ES, Williams D, Barry D. 2002. Analysis of the patterns of large fires in the boreal forest region of Alaska. Int $\mathrm{J}$ Wildland Fire 11:131-144.

Keeley JE, Fotheringham CJ. 2003. Impact of past, present, and future fire regimes on North American Mediterranean shrublands. In: Veblen TT, Baker WL, Montenegro G, Swetnam TW, editors. Fire and Climate Change in Temperate Ecosystems of the Western Americas. New York: SpringerVerlag. p 218-262.

Keeley JE, Fotheringham CJ, Morais M. 1999. Reexamining fire suppression impacts on brushland fire regimes. Science 284:1829-1832.

Keyser AR, Kimball JS, Nemani RR, Running SW. 2000. Simulating the effects of climatic change on the carbon balance of North American high-latitude forests. Global Change Biol 6 (Suppl. 1):185-195.

Kilgore BM, Taylor D. 1979. Fire history of a sequoia-mixed conifer forest. Ecology 60:129-142.

Levine JS. 1991. Global Biomass Burning: Atmospheric, Climatic, and Biospheric Implications. Boston: The MIT Press, Inc.
Miyanishi K, Johnson EA. 2001. A re-examination of the effects of fire suppression in the boreal forest. Can J Forest Res 31:1462-1466.

Mock CJ, Bartlein PJ, Anderson PM. 1998. Atmospheric circulation patterns and spatial climate variations in Beringia. Int $\mathrm{J}$ Climatol 10:1085-1104.

Murphy PJ. 2000. Historical fire records in the North American boreal forest. In: Kasischke ES, Stocks BJ, editors. Fire, climate change and carbon cycling in the North American boreal forests. New York: Springer-Verlag. p 275-288.

NIFC. 1992. Fire Behavior Field Reference Guide editors. Boise: National Interagency Fire Center, National Wildfire Coordinating Group.

Pyne SJ. 1982. Fire in America: A Cultural History of Wildland and Rural Fire. Princeton: Princeton University Press.

Pyne SJ. 2001. Year of the Fires: The Story of the Great Fires of 1910. New York: Viking.

Reap RM. 1991. Climatological characteristics and objective prediction of thunderstorms over Alaska. Weather Forecasting 6:309-319.

Roessler JS. 1997. Disturbance history in the Tanana River Basin of Alaska: Management options. M.S. Thesis University of Alaska Fairbanks.

Romme WH, Despain DG. 1989. Historical perspective on the Yellowstone fires of 1988. BioScience 39:695-699.

Schoennagel T, Veblen TT, Romme WH. 2004. The interaction of fire, fuels, and climate across Rocky Mountain forests. BioScience 54:661-676.

Serreze MC, and others. 2000. Observational evidence of recent change in the northern high-latitude environment. Climatic Change 46:159-207.

Stocks BJ, and others. 2002. Large forest fires in Canada, 1959-1997. J of Geophy Res 108:article 8149.

Swetnam TW. 1993. Fire history and climate change in giant sequoia groves. Science 262:885-889.

Todd SK, Jewkes HA. 2006. Fire in Alaska: A History of Organized Fire Suppression and Management in the last Frontier. Fairbanks: University of Alaska Fairbanks. 63 p.

Van Cleve K, Chapin FS III, Dyrness CT, Viereck LA. 1991. Element cycling in taiga forest:State-factor control. BioScience 41:78-88

Veblen TT, Kitzberger T, Donnegan JA. 2000. Climatic and human influences on fire regimes in Ponderosa pine forests in the Colorado Front Range. Ecol Appl 10:1178-1195.

Viereck LA. 1973. Wildfire in the taiga of Alaska. Quat Res 3:465-495.

Viereck LA, Dyrness CT, Van Cleve K, Foote MJ. 1983. Vegetation, soils, and forest productivity in selected forest types in interior Alaska. Can J Forest Res 13:703-720.

Viereck LA, Van Cleve K, Dyrness CT. 1986. Forest ecosystem distribution in the taiga environment. In: Van Cleve $\mathrm{K}$. Chapin FS III, Flanagan PW, Viereck LA, Dyrness CT, editors. Forest ecosystems in the Alaskan taiga. New York: SpringerVerlag.

Wein RW. 1976. Frequency and characteristics of arctic tundra fires. Arctic 29:213-222.

Yarie J. 1981. Forest fire cycles and life tables: a case study from interior Alaska. Can J Forest Res 11:554-562. 